\title{
Pemanfaatkan Video Kreatif dan Media Sosial Youtube sebagai Media Pembelajaran Matematika Kelas Tinggi
}

\author{
Desi Setiyadi $^{1}$, Dewi Fortuna ${ }^{2}, \&$ Anggy Bagas Ramadhan ${ }^{3}$ \\ Institut Daarul Qur'an Jakarta, Indonesia \\ Email:1desisetiyadi12@gmail.com, 2dewifor2000@gmail.com, \\ ramhanbagas@gmail.com
}

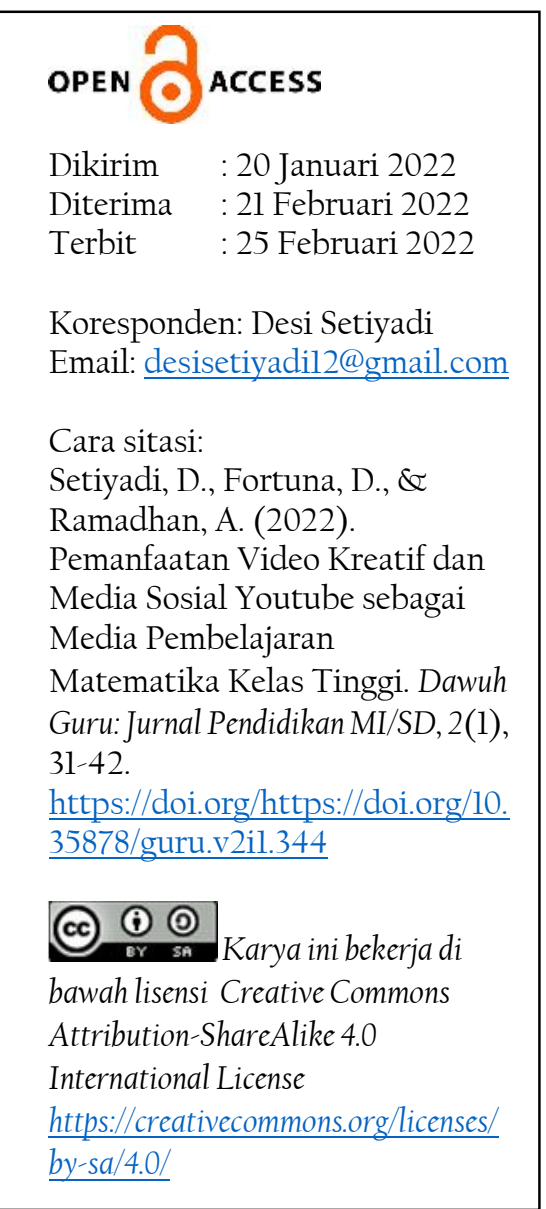

\begin{abstract}
This study aims to review how the mathematics learning media in high class during the pandemic era. The subjects of this study were in grade VI SD in the Cipondoh area. This type of qualitative research with a descriptive approach. Data collection techniques are surveys, documentation, and interviews for sixth grade math teachers. The results showed that during the COVID-19 pandemic, it was very difficult to explain in detail about volume units and other chapters because KBM was carried out online. The teacher then uses media in the form of creative videos and YouTube social media, so that students are interested in learning. Of the two media, the most frequently used by students is YouTube. In its implementation, there are several obstacles due to inadequate student facilities such as not having mobile phones, learning quotas, and parents who have not mastered technology.
\end{abstract}

Keyword: Video Creativity; Youtube; Learning Media

Abstrak
Penelitian ini bertujuan untuk meninjau
bagaimana media pembelajaran matematika
pada kelas tinggi saat era pandemi. Subyek
penelitian ini berada pada kelas VI SD di
daerah Cipondoh. Jenis penelitian kualitatif dengan pendekatan deskriptif. Teknik pengumpulan data yaitu survei, dokumentasi, dan wawancara guru matematika kelas VI. Hasil penelitian menunjukkan bahwa saat pandemi covid-19 ini sulit sekali untuk menjelaskan secara detail tentang satuan volume dan bab lainnya dikarenakan KBM dilaksanakan secara online. Guru kemudian memanfaatkan media berupa video kreatif dan media sosial youtube, agar peserta didik tertarik untuk belajar. Dari 
kedua media tersebut, yang paling sering digunakan oleh peserta didik adalah youtube. Dalam pelaksanaannya terdapat beberapa kendala disebabkan fasilitas peserta didik yang kurang memadai seperti tidak memiliki handphone, kuota belajar, dan orang tua yang belum menguasai teknologi.

Kata Kunci: Video Kreatifitas; Youtube; Media Pembelajaran

\section{A. Pendahuluan}

Virus Covid 19 awalnya berasal dari kota Wuhan Cina sejak desember 2019 dan menyebar sampai ke Indonesia yang saat ini disebut dengan virus corona. (Chandrasekaran \& Fernandes, 2020). Hasibuan \& Yusram (2020) pernyataan World Health Organization (WHO) menyatakan virus sangat cepat menyebar ke seluruh dunia sehingga menyebabkan wabah ini menjadi pandemic global. Pencegahan penyebaran corona setiap negera wajib menerapkan peraturan antara lain dengan cara social distanching untuk mencegah kerumunan dalam skala (Wilder-Smith \& Freedman, 2020).

Kondisi wabah ini mempunyai dampak pada dunia pendidikan, mulai yang paling bawah yaitu taman bermain hingga tingkat universitas. Hal ini menyebabkan perubahan metode pembelajaran dalam dunia pendidikan dari pembelajaran konvensional (tatap muka) menjadi daring dan luring (Napitupulu, 2020). Sejalan dengan itu, saat pandemi pembelajaran yang dilaksanakan berbeda dengan biasanya yaitu pembelajaran daring dan luring menuntut kerjasama guru, orangtua dan peserta didik (Khadijah \& Gusman, 2020). Anggapan mata pelajaran matematika yang sulit dipelajari oleh peserta didik menjadi momok terbesar saat menjadi pelajar (Setiyadi, 2021). Matematika berarti ilmu pengetahuan yang didapat dengan berpikir dan bernalar (Setiyadi, 2020).

Pembelajaran saat ini pendidik lebih mengeluarkan tenaga ekstra untuk menyampaikan setiap materi, dikarnakan KBM dilakukan secara online dan saat KBM berlangsung pendidik mendapatkan banyak kendala seperti fasilitas peserta didik yang kurang memadai, tidak adanya handphone, kuota internet, dan ada juga beberapa yang memiliki handphone namun untuk bekerja orang tuanya.

Berdasarkan hasil observasi, pendidik di SD daerah Cipondoh, Tangerang selalu mengupayakan yang terbaik agar terlaksananya pembelajaran sesuai dengan tujuan pendidikan. Pendidik menggunakan beberapa metode seperti metode kunjungan rumah (home visit), belajar dalam kelompok kecil dan shift (Suhendro, 2020).

Pendidik dituntut untuk lebih kreatif dan ekstra dalam mempersiapkan semua perangkat pembelajaran yang digunakan saat proses pembelajaran daring berlangsung berbeda dari sebelum terdampak pandemi covid 19, sehingga saat ini dapat menarik minat maupun semangat belajar peserta didik 
(Fahrina et al., 2020). Saat pandemi pendidik di SD daerah Cipondoh Tangerang berusaha untuk membuat video materi pembelajaran yang terbaik dan sekreatif mungkin namun pendidik lebih sering menggunakan media youtube untuk menunjang keberhasilan pembelajaran dikarenakan lebih simple dan mudah pendidik juga membekali setiap peserta didik dengan buku tema dan buku paket matematika yang di fasilitasi dari sekolah.

Era saat ini pendidik juga harus lebih memperhatikan beberapa hal yang penting seperti kondisi keluarga di rumah dan lingkungan sekitar (Ongie et al, 2020). Banyak sekali perbandingan ketika KBM dilaksanakan secara tatap muka dengan KBM pada saat pandemi. Menurut Suriadi, Firman \& Ahmad (2021) pembelajaran sekolah lebih efektif ketika dilaksanakan secara tatap muka karena pendidik dapat berinteraksi secara langsung dengan peserta didik, dan dapat memantau bagaimana perkembangan peserta didik dalam menangkap materi yang disampaikan, juga dapat mengontrol sikap setiap peserta didik.

Selain itu tentunya dapat memanfaatkan benda-benda di sekitar seperti; meja, lemari, penggaris dan lain- lain, sebagai contoh bentuk bangun ruang, menghitung satuan volume dan lain sebagainya (Septiani \& Safitri, 2021). Namun, menurut Lubis, et al (2020) ketika pandemi pendidik sulit sekali dalam mengekspresikan penyampaian materi untuk peserta didik dikarenakan hanya melalui grup whatsapp. Pendidik memberikan tugas harian yang menjawab bukan menjadi peserta didik melainkan orangtua dan lebih parahnya lagi mereka hanya menyalin jawaban dari google.

Itu juga yang dapat menghambat terlaksananya tujuan pendidikan. Selain itu, pendidik juga harus mendatangi rumah peserta didik yang tidak memiliki handphone agar tidak ada satupun peserta didik yang tertinggal dalam materi pembelajaran. Maka dituntutnya untuk melakukan pengembangan pada semua perangkat pembelajaran yang dapat mendukung dalam proses pembelajaran dan meningkatkan kualitas pembelajaran. Hal ini diharapkan hasil belajar pada setiap siswa dapat meningkat, meskipun pembelajaran dilakukan dengan menggunakan pembelajaran luring berbasis media pembelajaran teknologi. Oleh karena itu, tujuan dari penelitian ini yaitu meninjau bagaimana media pembelajaran matematika pada kelas tinggi saat era pandemi. 


\section{B. Metode Penelitian}

Jenis penelitian yang digunakan yaitu kualitatif dengan pendekatan deskriptif, yang artinya hasil yang diperoleh memaparkan tentang gambaran problematika pembelajaran daring dan luring peserta didik bagi guru dan orangtua. Subyek penelitian ini berada pada kelas VI SD di daerah Cipondoh. Jenis penelitian kualitatif dengan pendekatan deskriptif.

Teknik pengumpulan data yaitu survei, dokumentasi, dan wawancara guru matematika kelas VI. Validitas data yang didapatkan dalam penelitian dilakukan dengan triangulasi teknik. Data yang terkumpul dianalisis menggunakan teori analisis interaktif (Miles et al., 2014) dengan tahapan reduksi data, penyajian data, dan penarikan kesimpulan.

\section{Hasil dan Pembahasan}

Tafonao (2018) menyatakan media pembelajaran merupakan salah satu bagian terpenting dalam pembelajaran untuk mencapai tujuan. Namun, guru memilki problematika yaitu kurang memahami cara penggunaan aplikasi dan dalam pembuatan media pembelajaran audio visual yang diunggah ke aplikasi yang telah ditentukan. Hal ini dikarenakan usia guru yang sudah berumur sehingga kurang mengenal teknologi (Herliandry et al., 2020) serta kurangnya keterampilan dan pengetahuan guru tentang media pembelajaran berbasis teknologi.

Problematika orang tua yang mendampingi anaknya belajar daring yakni tidak dapat mengoperasikan media komunikasi internet yang sesuai saat pembelajaran. Dampak dari ketidaksiapan orang tua dan guru dalam pembelajaran daring ini menimbulkan stress dan kecemasan yang berlebihan, hal ini terjadi bukan hanya di Indonesia saja tetapi di belahan dunia.

Media pembelajaran yang digunakan di sekolah adalah video kreatif yang telah dibuat pendidik berisi tentang materi-materi pembelajaran matematika kelas VI seperti; bangun ruang, volume dan lain sebaganya. Video kreatif dibagikan melalui grup whatsapp untuk disaksikan oleh peserta didik. Menurut Batubara \& Ariani (2016) membuat video tersebut tidaklah mudah bagi guru, perlu usaha untuk mengedit agar menjadi sebuah video yang cantik nan menarik agar peserta didik tertarik untuk menonton video tersebut hingga akhir.

Video kreatif tersebut seperti gambar berikut.

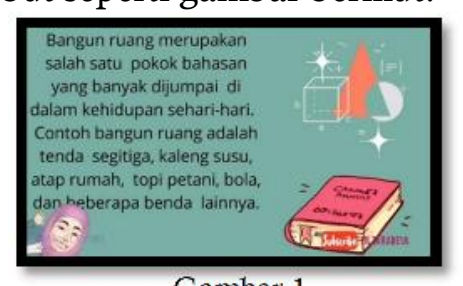

Gambar 1.

Contoh Video kreatif pendidik sebagai sarana pembelajaran matematika 
Menurut Rahmadayani, Lailatussaadah \& Dhin (2021) membuat video kreatif tersebut menyulitkan bagi pendidik, maka dari itu pendidik lebih sering memanfaatkan dan menggunakan media youtube sebagai sarana pembelajaran matematika pada kelas tinggi, dikarnakan lebih memudahkan pendidik (Pratiwi \& Hapsari, 2020). Youtube menyajikan berbagai varian pembelajaran sesuai kelas yang diinginkan seperti:

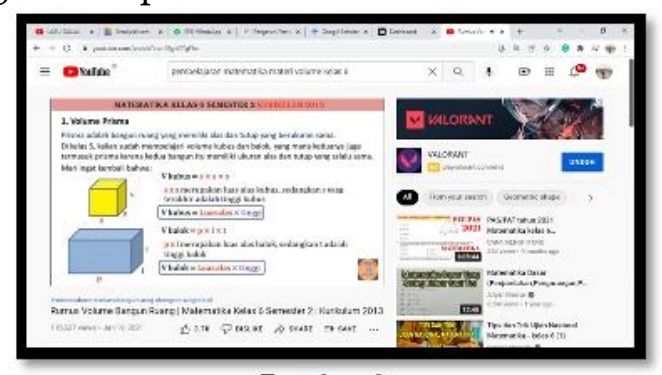

Gambar 2.

Media Youtube Sebagai Sarana Pembelajaran Matematika

Video kreatif ini berisi pemaparan materi-meteri matematika untuk kelas tinggi yaitu di kelas VI, kelebihan dari video kreatif ini selain memudahkan pendidik ialah memudahkan peserta didik pula dalam mempelajarinya bahkan video ini dapat diulang-ulang apabila peserta didik kurang paham dalam materinya yang telah dipaparkan oleh guru (Sudiarta \& Sandra, 2016). Hal ini memberikan kesempatan kepada peserta didik dengan orang tua yang mendampingi untuk belajar secara mandiri sampai memahami materi.

Kekurangan dari pembelajaran virtual ini ialah kurangnya fasilitas yang dimiliki oleh wali murid SDN daerah Cipondoh adapun yang memiliki fasilitas handphone namun digunakan oleh wali murid umtuk berkerja. Menurut Hariani, Arbaini \& Putri (2020) kendala lainnya yaitu seperti tidak adanya kuota belajar dan juga menurunnya rasa ingin belajar pada peserta didik karena merasa tidak tidak memiliki teman untuk bermain lain halnya ketika di sekolah mereka bisa bermain sambil belajar.

Menurut Dini (2021) faktor lainnya yaitu kasus komunikasi pula mempunyai problematika, penjelasan guru terkadang kurang jelas sehingga menciptakan pemahaman setiap orang tua memiliki perbedaan sebagai akibatnya output yg disampaikan kepada peserta didik berbeda. Selain itu lemahnya jaringan internet yang mejadi faktor penghambat waktu proses pembelajaran daring. Faktor yang terakhir merupakan kasus biaya, pada masa pandemic Covid 19 tentunya adanya penurunan hasil pendapatan dari orang tua (Duraku \& Hoxha, 2020).

Problematika dalam evaluasi terhadap output belajar anak ialah guru terkadang tidak mampu menilai secara objektif dan komprehensif terhadap hasil belajar peserta didik. Hal ini jelas kurang sejalan dengan prinsip-prinsip 
evaluasi yaitu 1) komprehensif (menyeluruh), 2) berkesinambungan, 3) objektif, 4) penilaian atas dasar alat ukur yang valid dan reliabel, serta 5) bermakna (Sugihartono, et al 2007). Pembelajaran daring di mana interaksi guru dengan peserta didik sebatas melalui layar laptop atau HP jelas menyulitkan penilaian yang objektif.

Problem ketidaksiapan pengajar dan orangtua sebagai problematika krusial pada memakai pembelajaran daring. Ada beberapa faktor yg menciptakan pengajar dan orang tua tidak siap pada menjalani pembelajaran daring diantaranya: Waktu, Tidak seluruh orangtua bisa membimbing atau memantau anaknya. Walaupun pemerintah menganjurkan pada warga buat selalu berada pada tempat tinggal, namun buat lokasi yang berada pada zona hijau, masyakat termasuk orang tua yang mempunyai anak usia dini wajib bekerja menggunakan tetap mematuhi protokol kesehatan.

Kodisi saat ini memungkinkan membuat aplikasi pembelajaran menyamakan ketika setiap peserta didik. Orangtua wajib membagi waktu antara pekerjaan tempat tinggal dan ketika membimbing anak ketika pembelajaran online. Sehingga orangtua mempunyai kesulitan, dan terkadang orangtua menyarankan pada pengajar ketika memakai pembelajaran daring jangan hanya menaruh penugasan saja, tetapi memberikan contoh yang memudahkan orangtua pada membimbing anaknya kapanpun (Sari \& Indrawati, 2017).

Kendala yang dialami ketika pembelajaran daring tidak menyurutkan SDN Cipondoh untuk melasanakan pembelajaran yang baik. Berbagai upaya telah dilakukan antara lain dengan memanfaatkan media kreatif dan media sosial Youtube. Meskipun mengalami berbagai kendala, tetapi video kreatif dan youtube mampu membantu peserta didik dalam memahami materi pelajaran. Dengan demikian maka guru harus terus berupaya meningkatkan kemampuan dalam memanfaatkan media digital bagi pembelajaran yang berkualitas.

Pemanfaatan video kreatif berbasis teknologi daring telah dilakukan, tetapi pembelajaran tatap muka masih sangat diperlukan. Oleh karenanya SDN Cipondoh mulai menerapkan KBM secara tatap muka yang dilaksanakan seminggu dua kali pertemuan dan dibagi menjadi 2 shift waktu pembelajaran. Pergantian antara waktu (pagi dan siang) untuk shift pertama yaitu berjumlah 15 murid dan pertemuan dilaksanakan pada pukul 07:00 - 09:00 WIB sedangkan shift kedua berjumlah 15 murid dan dilaksanakan pada pukul 11:00 - 13:00 WIB. Kegiatan tersebut sudah mulai berjalan sekitar 1 bulan dan tetap mematui protokol kesehatan seperti memakai masker, menggunakan handsinitizer, mencuci tangan, dan di cek suhu ketika memasuki area sekolah. Upaya tersebut dilakukan demi terwujudnya tujuan dalam pembelajaran. 


\section{Kesimpulan}

Hasil penelitian menunjukkan bahwa saat pandemi sulit sekali untuk menjelaskan secara detail tentang satuan volume dan bab lainnya dikarenakan pembelajaran dilaksanakan secara daring. Guru kemudian memanfaatkan media berupa video kreatif dan media sosial youtube, agar peserta didik tertarik untuk belajar. Dari kedua media tersebut, yang paling sering digunakan oleh peserta didik adalah youtube. Dalam pelaksanaannya terdapat beberapa kendala disebabkan fasilitas peserta didik yang kurang memadai seperti tidak memiliki handphone, kuota belajar, dan orang tua yang belum menguasai teknologi.

$* * * * * * * * *$

\section{Daftar Pustaka}

Agustian, N., \& Salsabila, U. H. (2021). Peran Teknologi Pendidikan dalam Pembelajaran. Islamika, $3(1)$,

123-133. https://doi.org/10.36088/islamika.v3i1.1047

Anshori, S. (2018). Pemanfaatan Teknologi Informasi Dan Komunikasi Sebagai Media Pembelajaran. Civic-Culture: Jurnal Ilmu Pendidikan PKn dan Sosial Budaya, 2(1). https://doi.org/10.33084/bitnet.v2i2.752

Asha, L. (2021). Strategi Kepala Sekolah Dalam Mengatasi Permasalahan Pembelajaran Online di Masa Pandemi COVID 19. Al-Ikhtibar: Jurnal Ilmu Pendidikan, 8(2), 79-96. https://doi.org/10.32505/ikhtibar.v8i2.626

Batubara, H. H., \& Ariani, D. N. (2016). Pemanfaatan video sebagai media pembelajaran Matematika SD/MI. Muallimuna, 2(1), 47-66. https://doi.org/10.31602/muallimuna.v2i1.741

Chandrasekaran, B., \& Fernandes, S. (2020). "Exercise with facemask; Are we handling a devil's sword?"-A physiological hypothesis. Medical hypotheses, 144, 110002. https://doi.org/10.1016/j.mehy.2020.110002

Dini, J. P. A. U. (2021). Problematika pembelajaran daring dan luring anak usia dini bagi guru dan orang tua di masa pandemi Covid 19. Jurnal Obsesi: Jurnal Pendidikan Anak Usia Dini, 5(2), 1825-1836. https://doi.org/10.31004/obsesi.v5i2.1013

Duraku, Z. H., \& Hoxha, L. (2020). The impact of COVID-19 on education and on the well-being of teachers, parents, and students: Challenges related to remote (online) learning and opportunities for advancing the quality of education.. Faculty of Philosophy, University of Prishtina. 
Ekayani, P. (2017). Pentingnya penggunaan media pembelajaran untuk meningkatkan prestasi belajar siswa. Jurnal Fakultas Ilmu Pendidikan Universitas Pendidikan Ganesha Singaraja, 2(1), 1-11.

Fahrina, A., Arahman, N., Mulyati, S., Aprilia, S., Mat Nawi, N. I., Aqsha, A., ... \& Matsuyama, H. (2020). Development of polyvinylidene fluoride membrane by incorporating bio-based ginger extract as additive. Polymers, 12(9), 2003. https://doi.org/10.3390/polym12092003

Farida, I., Aryanto, A., \& Sunandar, S. (2020). Strategi Pemberdayaan Pengecer dan Penjual Tradisional dalam Meningkatkan Daya Saing terhadap Pasar Modern di Wilayah Tegal. Jurnal Online Insan Akuntan, 5(1), 27-40. https://doi.org/10.51211/joia.v5i1.1316

Fepriyanti, U., \& Wiyani, N. A. (2020). Problematika Pembelajaran Jarak Jauh pada Keluarga Petani di MI Ma'arif NU Karanggedang 2 Purbalingga. Jurnal Kependidikan, 8(2), 191-206. https://doi.org/10.24090/jk.v8i2.4686

Hariani, F., Arbaini, W., \& Putri, D. P. (2020). Tingkat Pendidikan Orang Tua: Antar Motivasi Belajar Dan Kebiasaan Bermain Game Online. TA'DIBUNA: Jurnal Pendidikan Agama Islam, 3(1), 71-90. https://doi.org/10.30659/jpai.3.1.71-90

Hasibuan, E. M., \& Yusram, M. (2020). Hukum Salat Berjemaah di Masjid dengan Saf Terpisah Karena Wabah. BUSTANUL FUQAHA: Jurnal Bidang Hukum Islam, 1(2), 106-124. https://doi.org/10.36701/bustanul.v1i2.139

Herliandry, L. D., Nurhasanah, N., Suban, M. E., \& Kuswanto, H. (2020). Pembelajaran pada masa pandemi covid-19. JTP-Jurnal Teknologi Pendidikan, 22(1), 65-70. https://doi.org/10.21009/jtp.v22i1.15286

Hidayat, W. N., Sutikno, T. A., Patmanthara, P., Kartikasari, C. D. I., \& Firdaus, A. F. (2019). Peningkatan Keterampilan Pembuatan Media Pembelajaran Berbasis Augmented Reality Untuk Guru Smk. Jurnal Graha Pengabdian, 1(2), 93-103.

Huda, M., \& Adlina, R. (2021). Didikan seorang guru cerminan masa depan. Pembelajaran untuk Menjaga Ketertarikan Siswa di Masa Pandemi (Antologi Esai Mahasiswa Pendidikan Biologi), 100.

Ibnu Muttaqin, M. E. (2021). Komparasi Penggunaan Digital Tools pada Perkuliahan Daring di Masa Pandemi. JURUS JITU, 85, 1-10.

Januarti, N. E., \& Hendrastomo, G. (2018). Inovasi Pembelajaran Sosiologi Kurikulum 2013 melalui Pengembangan Media Pembelajaran Berbasis Teknologi Informasi. Habitus: Jurnal Pendidikan, Sosiologi, \& Antropologi, 2(1), 72-91. https://doi.org/10.20961/habitus.v2i1.20230

Khadijah, K., \& Gusman, M. (2020). Pola Kerja Sama Guru Dan Orangtua Mengelola Bermain Aud Selama Masa Pandemi Covid-19. Kumara Cendekia, 8 (2), 154. https://doi.org/10.20961/kc.v8i2.41871 
Khotimah, H., Supena, A., \& Hidayat, N. (2019). Meningkatkan attensi belajar siswa kelas awal melalui media visual. Jurnal Pendidikan Anak, 8(1), 17-28. https://doi.org/10.21831/jpa.v8i1.22657

Lubis, H. Z., Ginting, R. B., Sitepu, S. U. B., \& Mahyarani, D. (2020). Pembeajaran Keterampilan Berbicara Berbasis Daring (Stui Inovasi Pendidik di TK Aisyiyah Bustanul Athfal 5 Medan di Masa Wabah Covid 19). Hikmah, 17(1), 13-25. https://doi.org/10.53802/hikmah.v17i1.83

Lubis, M., \& Yusri, D. (2020). Pembelajaran Pendidikan Agama Islam Berbasis ELearning (Studi Inovasi Pendidik MTS. PAI Medan di Tengah Wabah Covid-19). Fitrah: Journal of Islamic Education, 1(1), 1-18. https://doi.org/10.53802/fitrah.v1i1.1

Miles, M. B., Huberman, A. M., \& Saldana, J. (2014). Cross-case data analysis.

In Qualitative data analysis: An expanded sourcebook(3rd ed.). Sage.

Myori, D. E., Chaniago, K., Hidayat, R., Eliza, F., \& Fadli, R. (2019). Peningkatan Kompetensi Guru dalam Penguasaan Teknologi Informasi dan Komunikasi melalui Pelatihan Pengembangan Media Pembelajaran Berbasis Android. JTEV (Jurnal Teknik Elektro dan Vokasional), 5(2), 102109.

Napitupulu, R. M. (2020). Dampak pandemi Covid-19 terhadap kepuasan pembelajaran jarak jauh. Jurnal Inovasi Teknologi Pendidikan, 7(1), 23-33. https://doi.org/10.21831/jitp.v7i1.32771

Nurrita, T. (2018). Pengembangan media pembelajaran untuk meningkatkan hasil belajar siswa. MISYKAT: Jurnal Ilmu-ilmu Al-Quran, Hadist, Syari'ah dan Tarbiyah, 3(1), 171-210. https://doi.org/10.33511/misykat.v3n1.171

Ongie, G., Jalal, A., Metzler, C. A., Baraniuk, R. G., Dimakis, A. G., \& Willett, R. (2020). Deep learning techniques for inverse problems in imaging. IEEE Journal on Selected Areas in Information Theory, 1(1), 39-56. https://doi.org/10.1109/JSAIT.2020.2991563

Prasetiyawati, P. (2020). Iklim Pembelajaran Matematika Di SMP. Jurnal VARIDIKA, 32(2), 56-66. https://doi.org/10.23917/varidika.v32i2.13137

Pratiwi, B., \& Hapsari, K. P. (2020). Kemampuan Berpikir Tingkat Tinggi Dalam Pemanfaatan YouTube Sebagai Media Pembelajaran Bahasa Indonesia. Jurnal Ilmiah Sekolah Dasar, 4(2), 282-289. https://doi.org/10.23887/jisd.v4i2.24238

Priyanto, A., \& Ag, M. (2020). Pembelajaran Daring. Penerapan Adaptasi Kebiasaan Baru pada Era Pandemi Virus Corona 19 di Berbagai Sektor Pendidikan, 41. 
Rahmadayani, I., Lailatussaadah, L., \& Dhin, C. N. (2021). Kreativitas Guru Bersertifikasi Dalam Pemanfaatan Media Pembelajaran Di Madrasah Ibtidaiyah Negeri (Min) 2 Banda Aceh (The Creativity of Certified Teacher in Utilizing Learning Media in Madrasah Ibtidaiyah Negeri (MIN) 2 Banda Aceh). Jurnal Ilmiah Didaktika: Media Ilmiah Pendidikan dan Pengajaran, 21(2), 151-161. https://doi.org/10.22373/jid.v21i2.7994

Salsabila, U. H., Lestari, W. M., Habibah, R., Andaresta, O., \& Yulianingsih, D. (2020). Pemanfaatan teknologi media pembelajaran di masa pandemi covid-19. Trapsila: Jurnal Pendidikan Dasar, 2(2), 1-13. https://doi.org/10.30742/tpd.v2i2.1070

Salsabila, U. H., Sukriyanto, R., Purwanti, E., Purwaningsih, P., \& Satria, M. I. A. (2021). Peran Orang Tua Dalam Penggunaan Teknologi Pada Pembelajaran Online Tingkat Sd Di Masa Pandemi Covid-19. Jurnal Inovasi Penelitian, 1(8), 1717-1721

Sari, A., \& Indrawati, D. (2017). The Use of Learning Media with MOODLE Approach to Improve the Quality of Education: A Literature Study. https://doi.org/10.2991/ictte-17.2017.33

Septiani, W., \& Safitri, D. M. (2021). Desain Ruang Kerja yang Ergonomis. Nas Media Pustaka.

Setiyadi, D. (2020). Analisis Kemampuan Pemecahan Masalah Ditinjau Dari Gaya Belajar Siswa Sekolah Dasar. JISPE: Journal of Islamic Primary Education, 1(1), 1-10. https://doi.org/10.31000/prima.v4i1.2079

Setiyadi, D. (2021). Pengembangan Bahan Ajar Bernuansa Etnomatematika dengan Permainan Tradisional Banyumas pada Sekolah Dasar. Jurnal Kiprah, 9(1), 30-38. https://doi.org/10.31629/kiprah.v9i1.3213

Sudiarta, I. G. P., \& Sadra, I. W. (2016). Pengaruh model blended learning berbantuan video animasi terhadap kemampuan pemecahan masalah dan pemahaman konsep siswa. Jurnal Pendidikan dan pengajaran, 49(2), 48-58. https://doi.org/10.23887/jppundiksha.v49i2.9009

Sugihartono, F. K., Harahap, F., Setiawati, F. A., \& Nurhayati, S. R. (2007). Psikologi Pendidikan. Yogyakarta.

Suharti, S. (2021). Efektivitas penerapan media pembelajaran interaktif berbasis edmodo dalam menyongsong era revolusi industri 4.0 terhadap hasil belajar matematika siswa. Jurnal Cendekia: Jurnal Pendidikan Matematika, 5(2), 10251038. https://doi.org/10.31004/cendekia.v5i2.564

Suhendro, E. (2020). Strategi Pembelajaran Pendidikan Anak Usia Dini di Masa Pandemi Covid-19. Golden Age: Jurnal Ilmiah Tumbuh Kembang Anak Usia Dini, 5(3), 133-140. https://doi.org/10.14421/jga.2020.53-05 
Suriadi, H. J., Firman, F., \& Ahmad, R. (2021). Analisis Problema Pembelajaran Daring Terhadap Pendidikan Karakter Peserta Didik. Edukatif: Jurnal Ilmu Pendidikan, 3(1), 165-173. https://doi.org/10.31004/edukatif.v3i1.251

Tafonao, T. (2018). Peranan media pembelajaran dalam meningkatkan minat belajar mahasiswa. Jurnal Komunikasi Pendidikan, 2(2), 103-114. https://doi.org/10.32585/jkp.v2i2.113

Utami, F. T., \& Zanah, M. (2021). Youtube Sebagai Sumber Informasi Bagi Peserta Didik di Masa Pandemi Covid-19. Jurnal Sinestesia, 11(1), 78-84. https://doi.org/10.53696/27219283.64

Wibisono, T., \& Mulyani, Y. S. (2019). Efektivitas pajak bumi bangunan perdesaan dan perkotaan terhadap Pendapatan Asli Daerah (PAD) di Kabupaten Tasikmalaya. Jurnal Ecodomica, $3(2)$. https://doi.org/10.31311/jeco.v3i2.5841

Wilder-Smith, A., \& Freedman, D. O. (2020). Isolation, quarantine, social distancing and community containment: pivotal role for old-style public health measures in the novel coronavirus (2019-nCoV) outbreak. Journal of travel medicine, 3(1), 469-482. https://doi.org/10.1093/jtm/taaa020

Zahroh, H. (2017). Pengembangan model bahan ajar video kreatif terpimpin edukatif (KTE) untuk pembelajaran menulis karya ilmiah sederhana peserta didik kelas IX SMP Mamba'unnur Bululawang. JINoP (Jurnal Inovasi Pembelajaran), 3(1), 469-482. https://doi.org/10.22219/jinop.v3i1.4281 
Pemanfaatkan Video Kreatif dan Media Sosial Youtube sebagai... 